Information Sciences in Europe: A Survey of Institutions of Education and Programmes

\author{
Thomas A. Schröder (Editorial management)
}

StudiengangInformationswissenschaft, PhilosophischeFakultät, Heinrich-Heine-UniversitätDüsseldorf, Düsseldorf, Deutschland

\title{
1 Introduction / Einleitung / Introduction
}

If you want to study Information Science in Europe you need more precise information about the possibilities in the various countries of Europe than for other fields of study.

Educational systems are still far from uniform in Europe. The diversity of opportunities is enormous, which makes it difficult for a person to obtain an overview. A European and even a national "corporate identity" of Information Sciences is still to be shaped.

Up to now, data on relevant courses of study in the field of Library and Information Science (LIS) ${ }^{1}$ could be found only in national study guides (United Kingdom ${ }^{2}$, Germany ${ }^{3}$ and France ${ }^{4}$ ), in worldwide address lists (Fang and Nauta ${ }^{5}$ ), or contained in the Students'

1 For Archive Science see: Répertoire des Ecoles et des courses de formation professionelle d'Archivistes / Directory of schools and courses of professional training for archivistes (Studies études, 6). Concil International des Archives / International council on Archivistes. Koblenz 1992

2 Armstrong, Ch. J. (1990): Information Studies Courses in the UK. Aldershot 1990

3 Gaus, W. (1992): Berufe im Archiv-, Bibliotheks-, Informations- und Dokumentationswesen. Ein Wegweiser zur Ausbildung. Berlin 2. Aufl. 1992

4 Soenen, H. (1990): Répertoire des Ecoles de langue Française en Science de 1'Information. 3ème Ed. Geneve 1990. A new edition is in preparation!

5 Riss Fang, J./ Nauta, P. (1992): International Guide to Library and Information Science Education (IFLA Publication 32). München 1992 


\section{(b]}

Handbook of the European Commission ${ }^{6}$, the UNESCO list ${ }^{7}$, the study guide of the DAAD (Deutscher Akademischer Austauschdienst) for individual European countries or in the annual edition of the "World of Learning". A study guide was required allowing the user to compare the study programmes offered in the field of Library and Information Science in Europe.

With "Information Sciences in Europe. A Survey of Institutions of Education and Programmes" we present a directory where one can find the programmes of more than 130 institutions in 30 European countries teaching in Information Science, Information Management, Library Science and Archive Science. All these programmes of study take place at universities or similar institutions and lead to an academic degree.

\section{Realisation of this Guide}

The realisation of this guide can be dated back to a discussion during the 2nd "Internationales Symposium für Informationswissenschaft" (ISI'91) in Oberhof/Thüringen (Germany) which was organized by the "Hochschulverband Informationswissenschaft". At the initiative of Thomas A. Schröder (M.A.) a team was formed at the Heinrich-Heine-Universität Düsseldorf (Germany) with the aim of creating an European and not just a national directory. At the 3rd "Internationales Symposium für Informationswissenschaft" (ISI '92) in Saarbrücken (Germany) Thomas A. Schröder and Christiane Niermann presented the results of the first initial inquiry upon a questionnaire to an expert public and invited its discussion.

Also at the 45th "Deutschen Dokumentartag" in 1993 (Jena/Germany) Thomas A. Schröder and Christiane Niermann presented a comprehensive analysis of the questionnaire ${ }^{8}$ The data collection was completed at the end of November 1993.

6 Studieren in Europa. Das Hochschulwesen in der Europäischen Gemeinschaft. Kommission der Europäischen Gemeinschaften. Amt für amtliche Veröffentlichungen der Europäischen Gemeinschaften. 6. Aufl. Köln 1990

7 Study abroad; Etudes à l'etranger; Estudios en el extranjero. United Nations Educational, Scientific and Cultural Organizations (UNESCO). 27th Ed. Paris 1991

8 Schröder, Th. A. / Niermann, Chr. (1994): Informationswissenschaftliche Studiengänge in Europa. Ergebnisse einer Befragung, in: Deutscher Dokumentartag 1993 (28.-30. September 1993, Friedrich-Schiller-Universität Jena). Deutsche Gesellschaft für Dokumentation. Frankfurt/Main 1994 
The preparation of the guide was more difficult and took a longer period of time than we had first thought. Europe is a many-membered and polyglot continent which cannot be subsumed under the dominance of one language like English. People cling to their native languages in the three large European countries (United Kingdom, Germany, France) and in many Eastern European countries German or French are favoured. The survey could only be carried out with a trilingual questionnaire, the choice of language was optional. So some entries in this study guide are found in Catalan, Polish, Italian and four addresses in Cyrillic.

We found that some institutions, even though they educate information professionals, are not very interested in giving out information about themselves. The first version of this innovative directory could thus only be based upon the information received and could not be comprehensive. We want to apologize for this and ask readers to kindly provide us with the missing information. Perhaps some experts might miss the institution they are in contact with. A blank form for amendments can be found on the last page. We have an e-mail address-list of many colleagues in Europe so we can pass on information via the electronic data nets or the Internet Gopher.

We cooperated with experts in the respective European countries to review our data material. A preprint of the study guide was sent to the electronic forums of the HI (Hochschulverband Informationswissenschaft) and ASIS (American Society of Information Science) for review and actualization.

\section{How to use this Guide}

The organizing features of this guide are in the English language. The first part includes all data concerning the institutions. The order is COUNTRY, CITY/INSTITUTION. The names of the countries are in English. The second part presents data on the programmes. The variety of names for study courses has been unified by an English expression in the category ACADEMIC SUBJECT in order to characterize the main subject of each programme. The exact name of the study course and the degree awarded can be found in the category "07".

Related data concerning the institution and programme are referred to with the symbol of a hand (1) and the page number. Addresses we give as far as possible in the original language with telephone and fax number in an international form. The e-mail address follows the agreement of Internet. 


\section{BD IV}

To facilitate comparisons of study organizations and degrees for the reader there is a graphic chart with academic degrees in Europe at the end of this introduction.

We tried to be correct about the educational situation of Information Sciences in Europe at the time of printing. Naturally some information can no longer be up to date when the guide appears. So we are not responsible for the correctness of the data. Only the information you obtain directly on inquiry from an educational institution can be legally binding.

\section{Word of thanks}

A publication like this would not be possible without the help of many friends. The searching, collecting, computerization, correction and layout of data, as well as the ever increasing communication by letter, fax, telephone and electronic post was teamwork. Thomas A. Schröder worked together with Christiane Niermann, Sonja Kempa, Peter Espenhahn and Oliver Coenen in the "Düsseldorf team". Other fellow students helped with special tasks. Simone Wagner made the necessary English translations and Richard Cenkier was the expert for Polish and Cyrillic texts. Alexander Sigel from Saarbrücken (Germany) initiated the discussion about educational questions. Harald Hiller from Graz (Austria) encouraged us during our work. The study guide would not have been realized if we had not been supported by Prof. Dr. Norbert Henrichs, and Dr. Michel J. Menou. Prof. Dr. Norbert Henrichs (Heinrich-HeineUniversität Düsseldorf) always found time to advise us and he made the resources of his institute available to us. The many European contacts of the chairman of the European Chapter of the American Society of Information Science, Dr. Michel J. Menou (Paris), were of great value for the taking up of data and finally the printing of the study guide. $\mathrm{He}$ established the contact with IOS Press as well as with the editors of Education for Information. We warmly thank the editors Dr. Andrew Large and Dr. Fred Guy for having accepted our guide as a Special Issue of EFI. 
Future aspects

The directory contains in its present form a representative survey of the educational situation in Europe and enables the user to understand and compare studies offered. We hope that the data and information offered in this guide will provide a practical and up-to-date basis for the international discussion of the study of Information Sciences in Europe. We hope that a second edition (if the readers would like it) will have an even larger data base and will contain constructive introductions on the study situation of individual European countries. We plan to create an electronic version of the directory like a hypertext disc and an online access via the world-wide Gopher system on the Internet (see in Gopher: Heinrich-Heine-Universität Düsseldorf $>$ Informationen aus der HHU $>$ Studium an der HHU $>$ Studienfächer $>$ Informationswissenschaft > Studienführer "Information Sciences in Europe").

This is not the end. It is not even the beginning of the end. But it is, perhaps, the end of the beginning.

(Winston Churchill, Mansion House, 10.11.1942) 


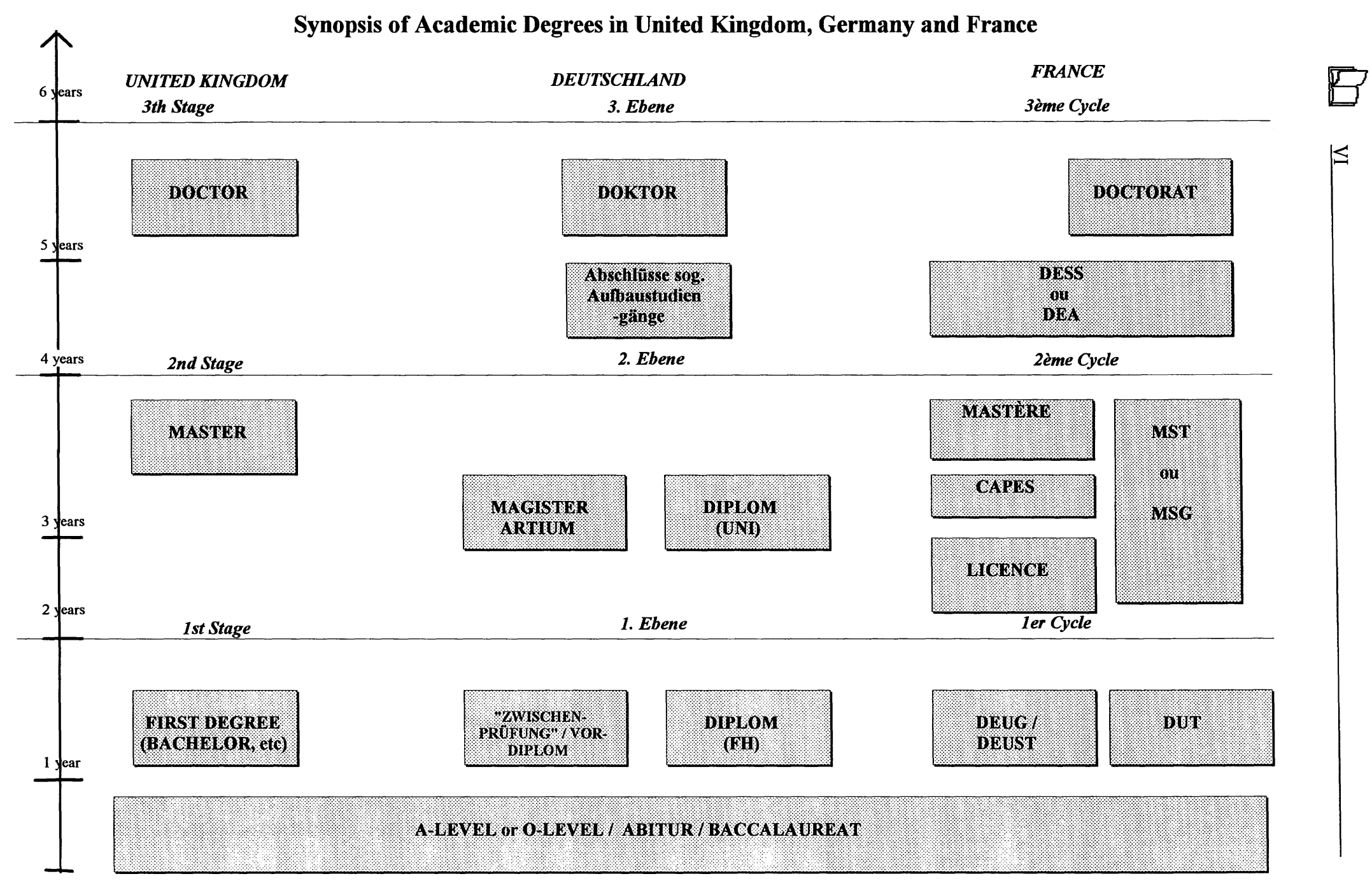

